\title{
THE ROLE OF COMMUNITY HEALTH CENTRES (PUSKESMAS) IN THE IMPLEMENTATION OF SEXUAL VIOLENCE PREVENTION FOR SCHOOL-AGE CHILDREN IN ELEMENTARY SCHOOLS
}

\author{
T Kartilah $^{1}$, S Februanti ${ }^{2}$, B Sakti $^{3}$, U A Hidayat $^{4}$ \\ ${ }^{1,2,4}$ Tasikmalaya Nursing Study Program, Health Polytechnic Tasikmalaya \\ ${ }^{3}$ Bandung Nursing Study Program, Health Polytechnic Bandung \\ Correspondence: ${ }^{1}$ tetetkartilah20@gmail.com; ${ }^{2}$ sofiafebruanti@gmail.com
}

\begin{abstract}
The number of events of sexual violence among school-age children in Indonesia is still high. Community health centres (puskesmas) have established school health centres (UKS). However, the methods implemented by the community health centres for preventing sexual violence among school-age children have not been identified, including primary, secondary, and tertiary preventions. This research aims to examine the prevention practices of sexual violence among school-age children conducted by community health centres. It employs qualitative method. The roles of community health centres in Tasikmalaya and Bandung in implementing the practices of sexual violence were identified through the school health centres (UKS) program. The findings indicate that in the primary prevention, the community health centres do not have specific programs; they perceived the sexual violence prevention as not being part of their responsibility. In terms of secondary prevention, the community health centres do not have the authority to monitor students' actions; the community health centres take actions based on schools' reports. In the tertiary prevention, the community health centres only provide health examinations for identifying sexual violence. Generally, the community health centres have not played specific roles in the primary, secondary, and tertiary prevention of sexual violence among school-age children.
\end{abstract}

Keywords: school-age children, sexual violence

\section{INTRODUCTION}

Children are the future as well as an asset of a nation. However, despite these projections, a problem like child abuse could threaten this asset. Child abuse is a global problem with serious life-long consequences. In Indonesia, the number of child abuse case is increasing from year to year. The term 'abuse' may refer to any emotional, sexual, or physical mistreatment, as well as neglect of a child [1]. This research will focus on prevention of child sexual abuse, which can be defined as unwanted sexual activity, with perpetrators using force, making threats or taking advantage of victims not able to give consent.

One out five women reported that they were sexually abused as a child [2]. Most of child sexual abuse victims are girls, averagely aged 15,4 years old or under 16 years old, with junior high school as their highest education [3]. According to the research conducted by Sisca and Moningka, most of sexual abuse perpetrators are known to the victim, e.g., 
neighbor, uncle, or people who work for the child's parent. All of those perpetrators are usually well known for being closely related to the victims [4].

There are many factors that cause child sexual abuse, like parents' carelessness, perpetrators' low mentality and morality, and [perpetrators'] low socio-economic conditions [5]. Furthermore, the fact that children have limited power to resist [the abuse] is also the main factor that preserves sexual abuse of children. If the victim is preteen, he/she is often threatened so that most of them are afraid to report their assault [6]. In Nigeria, one of sexual abuse major causes is irresponsible sexual behavior the teens have in their college days [7]. Meanwhile, from the perspective of law, sexual abuse occurs because of patriarchal value system where women are considered weaker than men; women are subordinated, marginalized, controlled, exploited, and enslaved by men and are considered to be second class citizens [8].

The consequences of sexual abuse may reflect in shape of lifelong physical injury as well as mental and financial injury. In the end, those consequences may affect socio-economic development of a nation [2]. On the victims, sexual abuse may cause depression and dysrhythmia, borderline personality disorder, somatization disorder, substance abuse disorder, post traumatic syndrome disorder, dissociative identity disorder, bulimia nervosa, suicidal tendency. It also may cause the victim to be more susceptible to infection of sexually transmitted diseases (STDs) including AIDS, to have unwillingness to go to school, to have a tendency to be a sexual abuse perpetrator in the future, to have a nightmare and anxiety disorder, to feel extremely sad, and to have a pregnancy at a young age $[3,9]$.

As everyone knows, children who were victim of sexual abuse may have a pregnancy, especially if they already get menstrual period. However, physically and mentally, they are not ready for pregnancy. When a young woman is pregnant before the age of 16 , she 
and her baby are at higher risk of health problems [10]. Therefore, an approach or program is needed to prevent children, especially girls, from getting sexually abused.

In this case, Puskesmas, as basic primary health care centers in sub-district level, should be able to help and take care of children who were abused sexually if it is needed; Puskesmas can refer them to hospital or other health care facilities for further treatment. Puskesmas should spearhead to provide health care for survivor of childhood sexual abuse. Thus, Puskesmas should develop a good managerial system that can handle child abuse incidences.

\section{METHODS}

In this research, qualitative approach was used for data analysis. Qualitative approach is a research paradigm used for describing event, human behavior or a situation at certain place in depth. The results are usually presented in a narration text.

People who participated in this research were the head(s) of Puskesmas (es) and responsible person of Puskemas' School's Infirmary (Puskesmas UKS) program in the city of Tasikmalaya and Bandung. For data analysis technique, descriptive narrative technique was chosen. This technique was implemented in three steps. They are 1) data reduction 2) data presentation 3) conclusion/verification. The data itself was collected by conducting observation, interview, and document analysis.

\section{RESULTS AND DISCUSSION}

This research involved the head of Puskemas in the city of Tasikmalaya and Bandung and a responsible person of Puskesmas UKS program.

\section{Primary Prevention}

In particular, puskesmas (es) in the city of Tasikmalaya and Bandung have not initiated primary prevention to prevent sexual abuse of school-aged children. This statement 
was made by responsible person of Puskesmas UKS program in the city of Tasikmalaya. Puskesmas does not have practical guide book for primary prevention [of child sexual abuse] either. In fact, puskesmas said that practical guide book is needed for teaching about preventing sexual abuse at schools or school's infirmaries (UKS)

"As [Puskesmas] UKS program administrator, I do not have specific guidance to teach [about sexual abuse prevention] at schools or school's infirmaries. In my opinion, this guidance is crucial because of the fact that school-aged children may be sexually abused by people they are familiar with...” $\mathrm{P} 1$

On the contrary, the head of a puskesmas in the city of Bandung stated:

“... [Primary prevention of child sexual abuse] has been implemented, but it is fragmented by the policy of respective Puskesmas. Apparently, practical guide program is needed to be initiated. We should not wait until a [child sexual abuse] case occurs. However, thank God there hasn't been a single case up to now ...” P2

Accordingly, parents and paramedics should be aware that [child sexual abuse] prevention is important. They also have to realize the fact that schools and puskesmas(es) cannot provide them with sexual abuse prevention guide. Primary prevention itself includes raising awareness of parents, teachers, and society to keep [school-aged] children safe not only at school, but wherever they are. However, there are many factors that affect their safety from sexual abuse, whether it is as perpetrator or victim. Therefore, parents have an important role to conduct child sexual abuse primary prevention.

A good practice of primary prevention is conducted by Tulungagung regency regional government. Tulungagung regional government has established Unit Layanan Terpadu Perlindungan Sosial Anak Integratif (ULT PSAI) or Integrative Service Unit for Children's Social Protection. This service unit coordinates with fellow governmental organizations in charge of children welfare to develop social service for children and to 
develop society-based forum and coordination. In this case, Puskesmas(es) in Tulungagung become the part of ULT PSAI network in sub-district level. ULT PSAI conducts primary prevention by holding parental classes, child issues campaign, and teaching children to use internet responsibly [11].

Particularly, Puskesmas(es) do not provide [parents and schools] with guide book for child sexual abuse primary prevention. The only guide book that they provide is $B u k u$ Kesehatan Ibu dan Anak (KIA) or Maternal and Child Health Handbook. This book gives a little information about protecting children from the risk of sexual abuse and sexual violence [12]. Moreover, the book's main target is children under the age of 6 . It does not cover guidance for school-aged child sexual abuse prevention. Therefore, Puskesmas(es) need to create practical guide book whose main target is school-aged children, so that these books can be used to help raising awareness.

In creating this guide book, Puskesmas(es) can refer to research findings regarding to child sexual abuse issues. Then, guide books can be distributed through teacher-in-charge in every school's infirmary. Printed media, such as handbook and booklet, is preferred because it is considered to be more effective to raise awareness than other media like posters or learning modules [13]. 


\section{Secondary Prevention}

Secondary prevention is almost similar to primary prevention. This prevention is implemented by giving guidance and information as well as motivation to avoid obscenity. Training, counseling, and assistance as secondary prevention are held by, of course, involving schools and parents in the process.

In a Focus Group Discussion (FGD), person in charge of of Puskesmas UKS in the city of Bandung said that:

“...Probably collaboration with other sectors is needed. Actually, a system [to enable the collaboration] is already established. We have UKS practitioner team, with regional secretary as superintendent. The team itself is more than capable, but they have not brought the best out in their people...." $\mathrm{P} 3$

The third participant/respondent said that a system for secondary prevention has been established, but the system has not reached optimal performance. Meanwhile, the head of Tasikmalaya Regional Puskesmas made following statement:

"If [sexual] misconduct occurs, it will be easier [for us] to take action. Problem solving approach can be applied when the problem has been successfully identified. Other parties should be more involved because children live in various places, with various backgrounds...” P4

In conducting secondary prevention, Puskesmas(es) particularly need a collaboration with other sectors, for example, P2TP2A. Pukesmas(es) actually has established a system for secondary prevention, although they have not optimized the function of the system. This research found the fact that Puskesmas(es) do not provide school's infirmaries with good facilities. The existence of school's infirmary is merely like a complementary for a school to be categorized as "standardized school". Managing UKS or school's infirmary is also seen as a burden by teacher in charge of school's infirmary. It is because unlike other duties of 
teachers, this duty does not become consideration in teaching performance assessment. Besides, teacher in charge of school's infirmary usually does not have competency background in child health care and child psychology.

Collaboration between society and government can also help Puskesmas to develop technical network with schools or educational institutions, so gradually, Puskesmas can share activities [with school students]. This collaboration is also a chance for Puskesmas to rebrand their institution, for all this time Puskesmas is only functioned as primary health care provider [14].

\section{Tertiary Prevention}

In conducting tertiary prevention, Puskesmas stated that schools may team up with P2TP2A to minimize the impact of child sexual abuse on the victim. The head of Tasikmalaya Regional Puskesmas made statement below

“....schools can team up with P2TP2A, or Pelayanan Kesehatan Peduli Remaja/PKPR (Teen Friendly Health Care) if there is one [at the nearest Puskemas]. Efforts are needed to lessen the impact [of child sexual abuse] on the victim and to prevent sexual abuse from occurring all over again."

Regional government and Puskesmas may also adopt that program in Tulungagung Regency. Tulungagung government has established Unit Layanan Terpadu Perlindungan Sosial Anak Integratif (ULT PSAI) or Integrative Service Unit for Children's Social Protection. This service unit coordinates with fellow governmental organizations in charge of children welfare to develop social service for children and to develop society-based forum and coordination. Puskesmas(es) in Tulungagung are part of ULT PSAI network in sub-district. ULT PSAI takes care of social problem facing children by providing prevention service (primary), reaching out vulnerable and high-risk groups (secondary), and supporting children 
who become sexual abuse victim (tertiary). Indirectly, Puskesmas(es) are able to do all those three kinds of prevention.

Puskesmas(es) have established health care program specifically for teens named PKPR. Students who are member of student council or OSIS at school know that there is PKPR at Puskesmas Kuta Selatan. However, many students do not know the function of PKPR due to lack of information [15].

\section{CONCLUSION}

The result of this research shows that when it comes to primary prevention of child sexual abuse, Puskesmas(es) do not have specific program to prevent child sexual abuse. That kind of prevention, per se, is not their responsibility alone. Puskesmas(es) also find a hard time to conduct secondary prevention, for they cannot look over every student's behavior [at every school]. In this case, they only take action if there is a report [about sexual abuse] from schools. Thus, Puskesmas(es) only have one chance to conduct child sexual abuse prevention. That is by conducting tertiary prevention. Other than providing health care for the victim of sexual abuse, in general, Puskesmas(es) do not have particular role in preventing child sexual abuse.

\section{REFERENCES}

[1] L. H. Garrett, "Sexual assault in the workplace.," AAOHN J., vol. 59, no. 1, pp. 15-22, 2011.

[2] WHO, "WHO | Child maltreatment," WHO, 2016. [Online]. Available: https://www.mendeley.com/library/\#. [Accessed: 05-Aug-2016].

[3] J. M. Darves-Bornoz, M. Choquet, S. Ledoux, I. Gasquet, and R. Manfredi, “Gender 
differences in symptoms of adolescents reporting sexual assault," Soc. Psychiatry Psychiatr. Epidemiol., vol. 33, no. 3, pp. 111-117, 1998.

[4] H. Sisca and C. Moningka, "Resiliensi perempuan dewasa muda yang pernah mengalami kekerasan seksual di masa kanak- kanak," J. Psikol., vol. 2 No. 1, pp. 6169, 2008.

[5] M. A. Fuadi, "Dinamika Psikologis Kekerasan Seksuak : Sebuah Studi Fenomenologi," Psikoislamika, J. Psikol. Islam, vol. 8 (2), no. 2, pp. 191-208, 2011.

[6] S. Fisnawati, G. Indriati, and V. Elita, "Hubungan Pengetahuan Orang Tua Tentang Kesehatan Seksual Pada Anak Usia 7-12 Tahun dengan Sikap Orang Tua Dalam Pencegahan Kekerasan Seksual," J. online Mhs. Bid. ilmu keperawatan, vol. 2, pp. 638-646, 2015.

[7] B. Odu, A. B. Falana, and O. A. Olotu, "Prevalence of Violent Sexual Assault on South West Nigeria Girls,” Eur. Sci. J., vol. 10, no. 7, pp. 471-481, 2014.

[8] M. Sumera, "Lex et Societatis, Vol. I/No.3/Juli/2013," Lex Soc., vol. Vol. I/No., no. 3, pp. 39-49, 2013.

[9] M. S. Friedman, M. P. Marshal, T. E. Guadamuz, C. Wei, C. F. Wong, E. M. Saewyc, and R. Stall, "A meta-analysis of disparities in childhood sexual abuse, parental physical abuse, and peer victimization among sexual minority and sexual nonminority individuals," Am. J. Public Health, vol. 101, no. 8, pp. 1481-1494, 2011.

[10] S. Reeder, L. Martin, and D. Koniak-Griffin, Maternity nursing: Family, Newborn, and women's health care. USA: Lippincott-Raven, 1997.

[11] Widowati, A. S. Cahyono, and M. D. Lestari, "Peran ULT PSAI kabupaten tulungagung dalam mengadvokasi permasalahan sosial anak," in SenasPro2, 2017, pp. $1161-1171$.

[12] L. Kurniasari, "Buku KIA dan pemanfaatan untuk peningkatan kesehatan ibu dan 
anak," J. Kesehat. Masy. Uwigama, vol. 1, no. 3, pp. 136-144, 2017.

[13] A. M. Arsyati, H. Pratomo, I. Ismail, S. Prasetyo, R. Damayanti, and J. Barat, “Pengembangan media cetak pendidikan pencegahan kekerasan seksual balita di Bogor," Hear. J. Kesehat. Masy., vol. 5, no. 1, 2017.

[14] W. P. Mulyani, T. Winarni, Harsoyo, and Nurhadi, "Model perlindungan anak berbasis masyarakat," in seminar nasional kependudukan dan kebijakan publik, 2017, pp. 113130.

[15] R. Winaningsih, "Persepsi remaja terhadap pelayanan kesehatan peduli remaja di wilayah Puskesmas Kuta Selatan,” Universitas Udayana, 2015. 